\title{
Biodiesel: An Alternative Fuel and Its Emission Effect
}

\author{
Yogendra Prasad Upadhyay ${ }^{1}$, R.B.Sharma ${ }^{2}$ \\ ${ }^{I}$ M.Tech.(Automobile Engineering) Research scholars RJIT BSF ACEDEMY Tekanpur, Gwalior, M.P., India \\ ${ }^{2}$ Hod of Mechanical Engineering department RJIT BSF ACEDEMY Tekanpur, Gwalior, M.P., India
}

\begin{abstract}
Biodiesel is an alternative fuel for diesel engines that is produced by chemically combining vegetable oils and animal fats with an alcohol to form alkyl esters. Fatty acid methyl esters (FAME) are produced by transesterification of vegetable oil with methanol usually in presence of an alkaline catalyst.This research studies the optimum condition of soya diesel production by methanol alkaline transesterification reaction between soybean cooking oil and methanol, ethanol and butanol using Some important variables such as volumetric ratio, types of reactants and catalytic activities were selected to obtain a high quality biodiesel fuel with the specification of American Society for Testing and Materials (ASTM D 6751) and European Norm (EN 14214).The exhaust emissions like carbon monoxide (CO) and smoke emissions were decreased while the NOx emissions were increased with SBD at full load compared to that of the base engine. The peak pressure and heat release rate were increased and the ignition delay and combustion duration were decreased for the internal combustion engine piston with SBD compared to that of the base engine.
\end{abstract}

Keywords: Fatty acid methyl esters (FAME), Soybean Cooking Oil, Soybean Bio Diesel (SBD) Emission, Nox

\section{Introduction}

The esters of vegetable oils and animal fats are known collectively as biodiesel, a renewable alternative fuel that has been shown to be direct replacement for diesel fuel incompression ignition engines. Biodiesel has an energy contentthat is about $12 \%$ less than petroleum-based diesel fuelon a mass basis. It has a higher molecular weight, viscosity, density, and flash point than diesel fuel. When biodiesel iscompared to conventional diesel fuel in engine tests, thepower and fuel consumption are in nearly direct proportionto the fuel's energy contents. Biodiesel is an oxygenatedfuel, $10 \%$ to $11 \%$ oxygen by weight, and produces lessunburned hydrocarbons (HC), carbon monoxide (CO), and particulate matter (PM) than diesel-fueled engines. Carbondioxide $(\mathrm{CO} 2)$ is recycled through the process of photosynthesisin growing the oilseeds making biodiesel nearly CO2neutral. Oxides of nitrogen (NOx) are increased by $10 \%$ to $15 \%$ when fueling with $100 \%$ biodiese $^{[1-2]}$. Biodiesel fuels aregood for the environment becausethey are also readily biodegradable,a benefit in case of spills. The high viscosity and poor volatility are the major limitations of vegetable oils for their utilization as fuel in diesel engines. Because high viscous vegetable oils deteriorate the atomization, evaporation and air-fuel mixture formation characteristics leading to improper combustion and higher smoke emission. Moreover this high viscosity generates operational problems like difficulty in engine starting, unreliable ignition and deterioration in thermal efficiency. Converting to biodiesel is one of the options to reduce the viscosity of vegetable oils.

\section{Sources of biodiesel raw materials-}

Typical raw materials of biodiesel are rapeseed oil, canola oil, soybean oil, sunflower oil and palm oil. Beef and sheep tallow and poultry oil from animal sources and cooking oil are alsosources of raw materials. There are various other biodiesel sources: almond, andiroba (Carapa guianensis), babassu (Orbignia sp.), barley, camelina (Camelina sativa), coconut, copra, cumaru (Dipteryx odorata), Cynara cardunculus, fish oil, groundnut, Jatropha curcas, karanja (Pongamia glabra), laurel, Lesquerella fendleri, Madhuca indica, microalgae (Chlorella vulgaris), oat, piqui (Caryocar sp.), poppy seed, rice, rubber seed, sesame, sorghum, tobacco seed, and wheatVegetable oils are renewable fuels. They have become more attractive recently because of their environmental benefits and the fact that they are made from renewable resources. Vegetableoils are a renewable and potentially inexhaustible source of energy, with energy content close to that of diesel fuel. Global vegetable oil production increased from 56 million tons in 1990 to 88 million tons in 2000, following a below-normal increase. The source of this gain was distributed among the various oils. Global consumption rose 56-86 million tons, leaving world stocks comparatively tight A variety of biolipids can be used to produce biodiesel ${ }^{[6-7]}$. These are -

(a) virgin vegetable oil feedstock; rapeseed and soybean oils are most commonly used, though other crops such as mustard, palm oil, sunflower, hemp, and even algae show promise;

(b) waste vegetable oil;

(c) animal fats including tallow, lard, and yellow grease; and

(d) non-edible oils such as jatropha, neem oil, castor oil, and tall oil . 
Various oils have been in use in different countries as raw materials for biodiesel production owing to its availability. Soybean oil is commonly used in United States and rapeseed oil is used in many European countries for biodiesel production, whereas, coconut oil and palm oils are used in Malaysia and Indonesia for biodiesel production. In India and southeast Asia, the Jatropha tree (Jatropha cursas), Karanja (Pongamia pinnata) and Mahua (M. indica) is used as a significant fuel source. Commonly accepted biodiesel raw materials include the oils from soy, canola, corn, rapeseed, and palm. New plant oils that are under consideration include mustard seed, peanut, sunflower, and cotton seed. The most commonly considered animal fats include those derived from poultry, beef, and pork Rapeseed has been grown in Canada since 1936. Hundreds of years ago, Asians and Europeans used rapeseed oil in lamps. Cottonseed oil is used almost entirely as a food material. Sesame, olive, and peanut oils can be used to add flavor to a dish. Walnut oil is high-quality edible oil refined by purely physical means from qualitywalnuts. Algae can grow practically anywhere where there is enough sunshine. Some algae can grow in saline water. All algae contain proteins, carbohydrates, lipids and nucleic acids in varying proportions. While the percentages vary with the type of algae, there are algae types that are comprised up to $40 \%$ of their overall mass byfatty acids. The most significant distinguishing characteristicof algal oil is its yield and hence its biodiesel yield. According tosome estimates, the yield (per acre) of oil from algae is over 200times the yield from the best-performing plant/vegetable oils. Microalgae are the fastestgrowing photosynthesizing organisms.They can complete an entire growing cycle every few days $^{[4]}$.Approximately 46 tons of oil/hectare/year can be produced fromdiatom algae. Different algae species produce different amountsof oil. Some algae produce up to $50 \%$ oil by weight. The productionof algae to harvest oil for biodiesel have not been undertaken on acommercial scale, but working feasibility studies have been conductedto arrive at the above number. Specially bred mustard varietiescan produce reasonably high oil yields and have the addedbenefit that the meal left over after the oil has been pressed outcan act as an effective and biodegradable pesticide

\section{Transesterification reaction}

Transesterification reaction was occurred using different types of alcohol performed at volumetric ratio 1:6 of oil to methanol, oil to ethanol and oil to 1-butanol using $\mathrm{KOH}$ catalyst. Transesterification reaction took place using methanol and ethanol and butanol at different volumetric ratio of oil to methanol, ranging from 4:1, 3:1, 1:3, 1:4 and $1: 6$ at $40^{\circ} \mathrm{C}$ and $320 \mathrm{rpm}$. The reaction time was maintained 3 hours constantly for all experiments. Two types of catalysts,

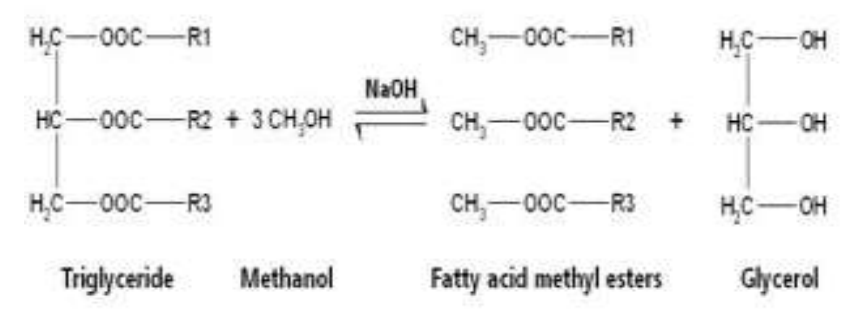

Figure-1, Transestrification process

$\mathrm{NaOH}$ and $\mathrm{KOH}$ have been used to come about the transesterification reaction at $1.0 \%(\mathrm{w} / \mathrm{v})$ concentration having volumetric ratio $1: 6$ of oil to methanol. The $\mathrm{KOH}$ has been used at a concentration of $0.5,1.0,1.5$, and $2.0 \%(\mathrm{w} / \mathrm{v})$ of oil having volumetric ratio 1:6 of oil to methanol. After transesterification reaction the biodiesel was separated from glycerol using separating funnel and finally washed with $5 \%$ water followed by magnesium sulfate anhydrous to remove the water. Catalyst type and concentration, methanol to oil ratio and reaction temperature of transesterification were investigated as they played a significantly difference in biodiesel produced $^{[5-6,8-9]}$

Technical properties of biodiesel

\begin{tabular}{|l|l|}
\hline Common name & Biodiesel (bio-diesel) \\
\hline Common chemical name & Fatty acid (m)ethyl ester \\
\hline Chemical formula range & $\begin{array}{l}\mathrm{C}_{14}-\mathrm{C}_{24} \text { methyl esters } \\
\text { or } \\
\mathrm{C}_{15}-25 \mathrm{H}_{28}-48 \mathrm{O}_{2}\end{array}$ \\
\hline $\begin{array}{l}\text { Kinematic viscosity } \\
\text { range (mm2/s, at 313 K) }\end{array}$ & $3.28-5.25$ \\
\hline
\end{tabular}




\begin{tabular}{|l|l|}
\hline $\begin{array}{l}\text { Density range (kg/m3, at } \\
\text { 288 K) }\end{array}$ & $855-898$ \\
\hline Boiling point range (K) & $>474.9$ \\
\hline Flash point range (K) & $418-450$ \\
\hline Distillation range (K) & $472-605$ \\
\hline $\begin{array}{l}\text { Vapor pressure (mm Hg, } \\
\text { at 295 K) }\end{array}$ & $<4.99$ \\
\hline Solubility in water & Insoluble in water \\
\hline Physical appearance & $\begin{array}{l}\text { Light to dark yellow, } \\
\text { clear liquid }\end{array}$ \\
\hline Odor Light & musty/soapy odor \\
\hline Biodegradability & $\begin{array}{l}\text { More biodegradable than } \\
\text { diesel }\end{array}$ \\
\hline Reactivity & $\begin{array}{l}\text { Stable, but avoid strong } \\
\text { oxidizing agents }\end{array}$ \\
\hline
\end{tabular}

\section{ENVIRONMENTAL IMPACT}

The processing of soy seed to produce soy oil gives rise to generation of substantial quantity of water pollutants, gaseous emissions and hazardous as well as non-hazardous solid waste. The pollutant generation is particularly high in solvent extraction and refinery. It means that soy oil industry is one of the highly polluting industries. The soy seed preparation section involves use of various machines leading to noise pollution. The captive power generating facility like boiler, DG sets are also the sources

Leakage and emission of chemicals (hexane, caustic, sulfuric acid, phosphoric acid, etc.) during storage, loading, unloading and usage of noise pollution. The coal-fired boiler generates fly ash, suspended particulate matter, smoke, and Carbon dioxide $\left(\mathrm{CO}_{2}\right)$. The spillage, give rise to toxic emission which spread in the work environment which has detrimental impacts on work force. The process wastewater discharged from the refinery is polluted. The bio-chemical treatment of the wastewater (in the Effluent Treatment Plant) gives rise to generation of sludge, a solid waste ${ }^{[10-11]}$.

Table-1.1 Major pollutants in soy oil industries

\begin{tabular}{|c|c|}
\hline Types of Pollution & Pollutants \\
\hline Air/Gaseous & Hexane, $\mathrm{SO}_{\mathrm{X}}, \mathrm{CO}_{\mathrm{x}}, \mathrm{NO}_{\mathrm{x}}$, Acidic Fumes, Dust etc. \\
\hline Liquid & $\begin{array}{l}\text { Acids (Sulphuric, Phosphoric, \& Fatty), Gum, Soap Stock, steam } \\
\text { Condensate, Cooling water, Process waste water etc. }\end{array}$ \\
\hline Solid & $\begin{array}{l}\text { Sludge, Slurry, Spent Bleaching Earth, Fly Ash \& Bottom Ash from } \\
\text { Coal Fired Boiler etc. }\end{array}$ \\
\hline Noise & Noise from seed cleaner, cracker, boiler \& DG sets \\
\hline Odor & $\begin{array}{l}\text { Due to degraded material in drainage, Acid Oil Recovery Plant and } \\
\text { Effluent Treatment Plant etc. }\end{array}$ \\
\hline
\end{tabular}

Table-1.2 Environmental Impacts/Effects of soybean oil industries

\begin{tabular}{|c|c|}
\hline Sources (Activities) & $\begin{array}{l}\text { Environmental } \\
\text { Impacts/Effects }\end{array}$ \\
\hline Water intensive oil refining operations & Depletion of water reserve \& generation of waste wates \\
\hline $\begin{array}{l}\text { Combustion of coal in the boiler-emission of } \mathrm{CO}_{2} \\
\& \mathrm{SO}_{2}\end{array}$ & $\begin{array}{l}\text {-Green House Effect } \\
\text { Acid rain }\end{array}$ \\
\hline Release of hexane from Solvent Extraction Plant & Toxicity in the work environment \\
\hline $\begin{array}{l}\text { 1-Release of sulfuric acid \& phosphoric acid from } \\
\text { storage vessel and processes } \\
\text { 2-Seed handling (loading, unloading \& cleaning) } \\
\text { 3-Handling of fly ash, from the boiler } \\
\text { 4-Emission of suspended particulate matter (SPM) } \\
\text { through boiler stack } \\
\text { 5-Coal crushing for boiler feed } \\
6 \text {-Handling of DOC }\end{array}$ & Dust in the work environment \\
\hline $\begin{array}{l}\text { 1-Seed mechanical sereening } \\
\text { Seed crushing } \\
\text { 2-Coal crushing } \\
\text { 3-Boiler operation } \\
\text { 4-DG set running }\end{array}$ & Noise nuisance in the work environment \\
\hline $\begin{array}{l}\text { Bio degradation of gum \& soap atock, spilled over oil, } \\
\text { DOC, Biological treatment of process wastewater etc }\end{array}$ & Odour nuisance in the work environment \\
\hline $\begin{array}{l}\text { 1-Spillage/leakage of sulfuric acid \& phosphoric acid, } \\
\text { soap stock, acid oil, refined oil etc } \\
\text { 2-Unsecured disposal of chemical containers }\end{array}$ & Contamination of soil/water \\
\hline
\end{tabular}




\section{Conclusion}

There are significant advantages in the use of biodiesel as a replacement of diesel fuel and in blends. The vegetable oils used as raw materials can be obtained from different oil crops that may be grown in a wide variety of environments, some of which are not adequate for traditional agricultural production. Microalgae grown in ponds and photo biological reactors have also great potential for the production of oils for biodiesel production. Moreover, used cooking oils and fat residues from the meat processing industry may also be employed in biodiesel production. The production process has the same stages, irrespective of the production scale, although the differences in equipment may be significant. After the treatment of the raw materials, the transesterification reaction (usually with methanol and a basic catalyst) produces a mixture of fatty acids methyl esters (FAME) with glycerin as a co-product. The mixture of methyl esters must be separated from the glycerin and purified in order to comply with the requirements set by international standards for biodiesel. The main disadvantages of biodiesel are its higher viscosity, lower energy content, higher cloud point and pour point, higher nitrogen oxide emissions, lower engine speed and power, injector coking, engine compatibility, and high price. Blends of up to $20 \%$ biodiesel mixed with petroleum diesel fuels can be used in nearly all diesel equipment and are compatible with most storage and distribution equipment. Biodiesel can be used directly or as blends with diesel fuel in a diesel engine. Biodiesel is a biodegradable and renewable fuel. It contributes no net carbon dioxide or sulfur to the atmosphere and emits less gaseous pollutants than normal diesel. Carbon monoxide, aromatics, polycyclic aromatic hydrocarbons (PAHs) and partially burned or unburned hydrocarbon emissions are all reduced in vehicles operating onbiodiesel. Recently, biodiesel has been receiving increasing attention due to its less polluting nature and because it is a renewable energy resource as against the conventional diesel, which is a fossil fuel leading to a potential exhaustion. Biodiesel has become more attractive recently because of its environmental benefits. Biodiesel is an environmentally friendly fuel that can be used in any diesel engine without modification. Biodiesel fuels have generally been found to be nontoxic and are biodegradable, which may promotetheir use in applications where biodegradability is desired. Neat biodiesel and biodiesel blends reduce particulate matter (PM),hydrocarbons (HC) and carbon monoxide (CO) emissions and slightly increase nitrogen oxides (NOx) emissions compared with petroleum-based diesel fuel used in an unmodified diesel engine

The magnitude of our energy needs provides an inexhaustible market for our total agricultural production capacity at the highest possible level. We could put the farm back to work providing for our food needs and also growing crops and livestock for energy. Energy is the only crop that could never grow in surplus.

\section{References}

[1] Knothe G, Dunn RO, and Bagby MO (1997) Biodiesel: the use of vegetable oils and their derivatives as alternative diesel fuels. In: Fuels and Chemicals from Biomass, 1st edn.

[2] American Chemical Society, New York Van Gerpen J, Shanks B, Pruszko R, Clements D, Knothe G (2004) Biodiesel production technology. National Renewable Energy Laboratory, NRRL/SR-510-36244 242 Introduction to Biodiesel Production

[3] Van Gerpen J, Shanks B, Pruszko R, Clements D, Knothe G (2004) Biodiesel analytical methods. National Renewable Energy Laboratory, NRRL/SR-510-36240

[4] Romano SD, González Suárez E, Laborde MA (2006) Biodiesel. In: CombustibleAlternatives', 2nd edn. Ediciones Cooperativas, Buenos Aires

[5] Aggarwal, J.S., H.D. Chowdury, S.N. Mukerji, and L.C.

[6] Vermoh. 1952. Indian vegetable oil fuels for diesel engines. Bul. Indian Industrial Research No. 19.

[7] ASAE. 1982. Vegetable Oil Fuels. Proc. International Conference on Plant and Vegetable Oil as Fuels. 400 pp. St. Joseph, Mich.: ASAE.

[8] ASTM. 1999a. D 6078 - Diesel fuel scuff test method. West Conshohocken, Penn.: ASTM International.

[9] ASTM. 1999b. D 6079 - Standard test method for evaluating the lubricity of diesel fuels by the high frequency rotating rig. West Conshohocken, Penn.: ASTM International.

[10] STM. 2002. D 6751 - Standard specification for biodiesel fuel (B100) blend stock for distillate fuels. West Conshohocken, Penn.: ASTM International

[11] Dinas Perkebunan Propinsi Riau. 2007. Kelapa. www.litbang.deptan.go.id. (20 September 2007),

[12] http://www.biodiesel.org/pdf_files/OEM\%20Statements/Diesels_for_Sale_in_US.pdf

[13] http://www.epa.gov/otaq/fuels/renewablefuels/index.htm

[14] http://www.nrel.gov/vehiclesandfuels/pdfs/43672.pdf 